\title{
Correlation between $\gamma$-H2AX, micronucleus and annual occupational dose in medical radiation workers
}

\author{
I.K. Hasan Basri ${ }^{*}$, S. Barnard ${ }^{2}$, V.A. Suvivan', T. Rahardjo',

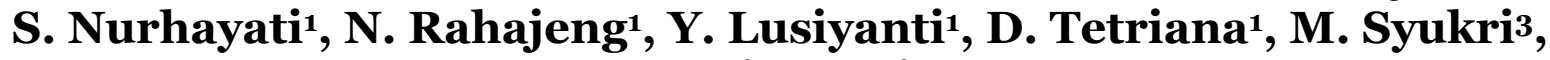 \\ S. Purnami' ${ }^{1}$ E. Hiswara ${ }^{1}$ \\ ${ }^{1}$ Department Center for Technology of Radiation Safety and Metrology Indonesia, National Nuclear Energy Agency, \\ Jalan Lebak Bulus Raya No. 49. Jakarta, 12440, Indonesia \\ 2Public Health England, Centre for Radiation, Chemical and Environmental Hazards, Chilton, Didcot, Oxon OX11 \\ ORQ, United Kingdom \\ 3M. Jamil Hospital, Jl. Perintis Kemerdekaan Padang, 25171, Indonesia
}

\begin{abstract}
- Original article

${ }^{*}$ Corresponding author:

Dr. Iin Kurnia Hasan Basri

E-mail: kurnia@batan.go.id

Revised: January 2021

Accepted: February 2021

Int. J. Radiat. Res., October 2021; 19(4): 1015-1023

DOI: $10.29242 /$ ijrr.19.4.1015

Background: Medical workers are exposed to long-term low levels of ionizing radiation, which makes them vulnerable to DNA damage. There are potential occupational health hazards from radiation exposure in a large occupational segment of the population. Matherials and Methods: During this study, 69 blood samples were taken from 45 medical workers (including diagnostic radiologists, radiographers, and cathlab nurses) and 24 nonmedical workers as controls from three hospitals across Indonesia, and were analyzed for the presence of DNA damage. Detection of $\mathrm{Y}-\mathrm{H} 2 \mathrm{AX}$ expression as a biomarker of DNA DSB damage and the micronucleus assay were carried out by immunofluorescence microscopy and Giemsa staining, respectively. Results: The mean $\mathrm{y}-\mathrm{H} 2 \mathrm{AX}$ foci index in workers was $0.02(0.00-0.24)$ and in control was $0.02(0.00-0.12)$, micronucleus frequency of workers (5-30 per 1000 cells) and control (12-29 per 1000 cells). The annual occupational dose of workers was recorded as (0.01-1.12 $\mathrm{mSv})$. There was no statistical difference in the mean number of $\mathrm{Y}-\mathrm{H} 2 \mathrm{AX}$ foci and the micronuclei frequency between workers and controls, but there was a small tendency toward correlation between $\mathrm{Y}-\mathrm{H} 2 \mathrm{AX}$ foci and micronuclei frequency and the annual occupational dose of workers. Conclusions: $\mathrm{Y}-\mathrm{H} 2 \mathrm{AX}$ foci have the potential to be used as a biomarker to detect radiation-induced DNA DSB damage in workers caused by occupational dose exposure.
\end{abstract}

Keywords: $\mathrm{Y}$-H2AX, micronucleus, occupational dose exposure, medical radiation workers.

\section{INTRODUCTION}

The extensive use of ionizing radiation as a diagnostic and therapeutic tool represents the largest man-made contribution to the radiation dose received by the general population (1). Medical workers are among the most frequently exposed to low doses of ionizing radiation (2). Their levels of exposure in hospitals have decreased below the regulatory limit in recent decades, even though the increasing use of relatively high-dose procedures, such as interventional cardiology, raises some concern (3-5). High doses of ionizing radiation are known to induce acute and chronic effects in humans, while the potential risk of detrimental effects related to low doses of radiation is still a matter of discussion $(6,7)$.

Medical radiation workers, including doctors, nurses, and other medical staff, are exposed to 
low doses of ionizing radiation from several sources, including diagnostic x-rays and other medical instruments (8). They constitute the largest occupational group exposed to man-made sources of radiation (9). Many medical uses of radiation, such as those in nuclear medicine, may cause staff exposure at higher doses. Nuclear medicine employees are continuously exposed to ionizing radiation in the workplace despite the use of radiation protection equipment (10).

Exposure to radiation initiates certain changes to proteins, carbohydrates, lipids, nucleic acids, and gene expression in exposed cell(s). This can be observed using various tools that are collectively defined as radiation biomarkers. In particular, ionizing radiation in a cellular system can bring about several changes such as base damage, alkylation, intercalation adduct formation, nucleotide modifications, and single-strand and double-strand breaks in the deoxyribonucleic acid (DNA) (11). These changes may result either from direct deposition of energy on the nucleic acids (direct action), or they can be mediated by the actions of free radicals released at some point during the interaction with water (indirect action) and membranes (lipid peroxidation) within the cells (12).

The scientific evidence, both from human population surveys and animal experiments, indicates that the risks related to low doses of radiation are mainly due to stochastic effects. The prime target of ionizing radiation is DNA. Ionizing radiation produces its genotoxic effect by inducing double-strand breaks (DSBs) and non-DSB highly clustered DNA lesions consisting of single-strand breaks (SSBs), a-basic sites, and oxidized bases. However, other effects associated with exposure to ionizing radiation in the low-dose region, referred to as non-targeted effects, include damage such as chromosomal aberrations, genomic instability, and cell death (11-14).

Following exposure to ionizing radiation, DNA double-strand breaks (DSBs) are formed at sites of DNA damage. One of the initial responses to the DSB is the phosphorylation of histone $\mathrm{H} 2 \mathrm{AX}$ protein. It forms gamma-H2AX $(\gamma-\mathrm{H} 2 \mathrm{AX})$ foci at the DNA damage sites within minutes (15). Each DSB site is believed to correspond to one microscopic $\gamma$-H2AX focus that rapidly forms and, depending on the functionality of the DNA repair response, is repaired. This is indicated by the disappearance or repair of foci at these sites. These foci repair at different rates over a period of up to 48 hours (16-19). They can be observed microscopically by the immunofluorescent $\gamma$-H2AX assay which immunostains the phosphorylated H2AX histone represented as $\gamma$-H2AX. Both the intensity of the fluorescent signal at individual DSB sites and the number of $\gamma$-H2AX foci is directly proportional to the amount of DSB formed (20).

Biological dosimetry is another method to estimate radiation exposure. It can be defined as the estimation of the received dose from past exposure to an agent through observation of biologic variables or measurements (21). For decades, biological dosimetry for radiation has been conducted by the use of the dicentric chromosome assay (DCA). DCA dose prediction is based on ionizing radiation-induced damage to DNA, which results in the formation of dicentric chromosomal aberrations (22-23). The chromosomal aberration, or dicentric assay, was one biodosimetry technique with low background levels and high specificity to ionizing radiation, making this assay a "gold standard" biodosimetry method and a diagnostic dose indicator recommended by the IAEA (24). The test includes the analysis of a large number of metaphases that require highly specialized personnel to analyze. The micronucleus (MN) assay in peripheral blood lymphocytes, as an indirect assessment of chromosomal aberrations, was applied as an alternative, as it allows much faster detection of aberrations compared to dicentric assay (25-29). The cytokinesis-block technique (CBMN) uses cytochalasin-B as a cytokinesis inhibitor. This allows the evaluation of micronuclei frequency in dividing cells accumulated in the binucleated cells to overcome the uncertainties associated with in vitro cell-division kinetics that can affect MN expression (30). In recent times, the micronucleus test has been employed more frequently to assess cytogenetic damage in

Int. J. Radiat. Res., Vol. 19 No. 4, October 2021 
populations exposed to ionizing radiation in their occupations. The results of these studies are contradictory; they do not help to establish a relationship between the exposure dose and the increase of chromosomal damage.

In an earlier work, we studied residents living in high background radiation to determine the exposures to different professions of medical workers. The results tended to show increased numbers of $\gamma$-H2AX foci compared to a control group. These increased numbers demonstrated the process of repairing DNA DSBs damage (31, 32). Increased frequencies of $\gamma-\mathrm{H} 2 \mathrm{AX}$ foci were not considered to be a direct result of annual occupational doses of these medical workers (32). The purpose of this study was to analyze the correlation between the frequency of both $\gamma-\mathrm{H} 2 \mathrm{AX}$ and micronuclei with respect to the annual occupational doses of medical workers. The results of $\gamma-\mathrm{H} 2 \mathrm{AX}$ and micronuclei will be useful to know the potential for the use of genomic damage biomarkers in workers receiving occupational dose exposures in their daily working.

\section{MATERIALS AND METHODS}

\section{Subjects}

The research protocol for this study was approved by the National Institute for Health Research and Development No. LB. 02.01/2.KE.132 \2018. During this study, 69 blood samples were collected from 45 volunteer medical workers including diagnostic radiologists, radiographers, and cathlab nurses and 24 non-medical staff as controls across three hospitals in Indonesia. Personal dosimeters were also incorporated for evaluation of the external exposure of each volunteer. The amount of radiation exposure to each individual was measured using thermo-luminescent dosimeters (TLD) following three months of occupational exposure. The exposure was expressed in $\mathrm{mSv}$ as the mean of the annual effective dose for the period of exposure. Occasionally, personal dosimetry was implemented using an automatic TLD reader (Harsaw Model 6600 with LiF:Mg Ti cards;
Thermo Scientific, 81 Wyman Street, Waltham, MA 02454). The glow curve was constructed from sophisticated data processing with Harsaw CGCD (computerized glow curve deconvolution) software (33).

All volunteers were informed about the nature, aims, and intention of the study, and eachsigned an informed consent form and associated questionnaire before providing blood samples. Any individual suffering from an illness or taking any medication was excluded from the study.

\section{Isolation of lymphocytes}

Two milliliters (ml) of whole blood was collected by intravenous injection from each individual. The Histopague separation method to isolate peripheral lymphocytes was used, as reported in previous papers by the authors (31, 32). The isolated lymphocytes in the buffy coat of the separated blood were transferred to a new $15 \mathrm{ml}$ centrifuge tube with $5 \mathrm{ml}$ of PBS to wash the cells. They were then centrifuged for a further $5 \mathrm{~min}$ at $1000 \mathrm{rpm}$. The cells were washed three times and resuspended in PBS at a density of (5-6) $\times 10^{4} / \mathrm{ml}$ and put on basic medium (RPMI). This method was adopted from previous publications without any modification $(20,34)$, centrifuged for $15 \mathrm{~min}$ at $1000 \mathrm{rpm}$.

\section{$\gamma-H 2 A X$ assay}

Lymphocytes were dropped and left for 15 min on hydrophobic slides, then fixed with $2 \%$ formaldehyde for $5 \mathrm{~min}$, permeabilized for $5 \mathrm{~min}$ with $0.25 \%$ Triton X-100, and finally blocked with $2 \%$ BSA (diluted in PBS) for $15 \mathrm{~min}$ at room temperature. After removing the BSA, the primary antibody (consisting of anti $\gamma$-H2AX (mouse anti-Phospho-Ser139 $\gamma$-H2AX antibody, Thermo Fisher) and 53BP1 antibodies (Thermo Fisher; used for internal control staining)) were mixed together in a 1:500 dilution in 2\% BSA/ PBS. The mixture was dropped on the slide-bound lymphocytes and kept for $1 \mathrm{~h}$ in a dark, moist chamber at room temperature. The first primary antibodies were then removed and the slides were incubated with BSA 2\% three times for $15 \mathrm{~min}$ each. Next, the secondary antibodies (consisting of goat anti-mouse IgG 
Daylight 488 and anti-rabbit-Daylight $594 \mathrm{~nm}$, both from Thermo Scientific) were diluted in BSA $2 \%$ and with DAPI (diluted 1:500). Slides were then incubated for $30 \mathrm{~min}$ at room temperature. Once this was completed, the slides were washed 2 or 3 times with PBS to remove excess antibody, and the slides were dried for 15 min using a fan. The mounting medium Vectashield with DAPI was used and mounted with a cover slip and left in the refrigerator for 24 hours prior to analysis. The observations were performed by an experienced investigator (IK) using a fluorescence microscope (Nikon) equipped with red, green, and blue fluorescence filters and using 100x magnification under immersion oil (32).

\section{Micronucleus assay}

The micronucleus assay was performed in cytokinesis-blocked lymphocytes using cytochalasin-B (Cyt-B), following as the method described by Fenech (29) with only a small modification. Blood cultures were incubated for $72 \mathrm{~h}$. After $44 \mathrm{~h}$ of incubation, cytochalasin-B (Cyt-B Sigma) was added to the cultures at a concentration of $6 \mathrm{~g} / \mathrm{ml}$ to block cytokinesis. The cells were isolated and collected by centrifugation, and a mild hypotonic solution containing $0.075 \mathrm{M} \mathrm{KCl}$ was then added for 3 min. After centrifugation and removal of the supernatant, the cells were fixed with a freshly prepared mixture of methanol/acetic acid (3:1). Centrifugation and resuspension were carried out three times and the cells were then dropped onto clean microscope slides for detection of micronuclei by conventional staining with $5 \%$ Giemsa. The evaluation was performed with a minimum of 1000 binucleated cells for each person scored for the presence of micronucleus according to the criteria described by Fenech (30).

\section{Statistical analysis}

After data were collected and analyzed, the Kolmogorov-Smirnov Test was applied to ensure the normality of distribution. The Mann Whitney Test was used to analyze data between $\gamma$-H2AX foci and micronulei index between the workers and the nonmedical staff (controls). Rank Correlation and Fit with Regression Line were used to analyze the correlation between $\gamma$ H2AX foci and micronulei index, and to compute the annual dose estimate of each medical worker. All data were analyzed with MedCalc Software 12.7.00.

\section{RESULTS}

The frequency of micronuclei in workers and controls ranged between 5-30 and 12-29 respectively. The range of mean $\gamma-\mathrm{H} 2 \mathrm{AX}$ foci per cell in workers and controls was 0.00-0.24 and 0.00-0.12 respectively. There was no statistical difference between mean $\gamma$-H2AX foci/cell and the micronuclei frequency between workers and controls ( $p>0.05$ ). Related data such as age, sex, and the habits of the volunteers can be seen in table 1. Even though there was no statistical difference in the $\gamma$-H2AX and micronuclei index between control and exposed (figure 1a and 1b), no statistical correlation between the mean $\gamma$-H2AX and micronuclei index was found. It is interesting to note the small tendency toward a negative correlation between $\gamma$-H2AX and the emergence of micronuclei (figure 2a), and the tendency toward a positive correlation between $\gamma$-H2AX and annual occupational doses (figure $2 b)$.

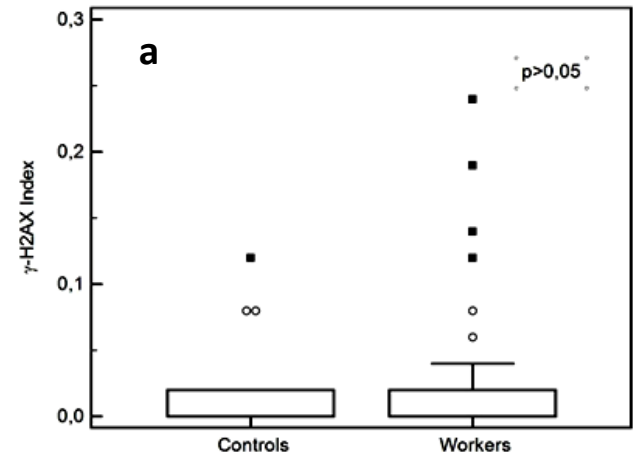

1018

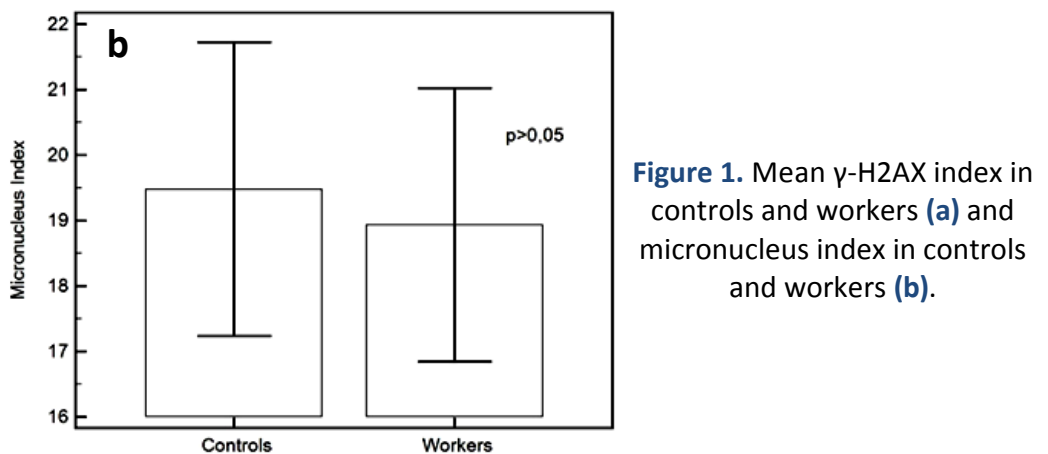

Int. J. Radiat. Res., Vol. 19 No. 4, October 2021 
Table 1. Distribution $\mathrm{Y}$ - H2AX, Micronucleus, and Occupational Dose of Workers and Controls.

\begin{tabular}{|c|c|c|c|c|c|c|c|}
\hline No & Code/Name & Ages (Years) & Sexes & $\mathrm{V}-\mathrm{H} 2 \mathrm{AX}$ & Micronucleus & Doses/Year (mili Sievert) & Smoking/No \\
\hline 1 & BS1 & 32 & W & 0,04 & 20 & 1,15 & No \\
\hline 2 & BS2 & 50 & $\mathrm{M}$ & 0,24 & 21 & 0,71 & No \\
\hline 3 & BS3 & 53 & $\mathrm{M}$ & 0,14 & 15 & 0,33 & No \\
\hline 4 & BS4 & 26 & $\mathrm{M}$ & 0 & 15 & 0,47 & No \\
\hline 5 & BS6 & 47 & W & 0,04 & 24 & 1,04 & No \\
\hline 6 & BS7 & 43 & $\mathrm{M}$ & 0,12 & 17 & 0,51 & No \\
\hline 7 & BS8 & 45 & $\mathrm{M}$ & 0,19 & 20 & 0,45 & No \\
\hline 8 & BS9 & 46 & W & 0 & 20 & 0,38 & No \\
\hline 9 & BS12 & 35 & W & 0 & 15 & 0,32 & No \\
\hline 10 & BS15 & 40 & W & 0 & 25 & 0,7 & No \\
\hline 11 & BS16 & 44 & $\mathrm{M}$ & 0 & 21 & 0,2 & No \\
\hline 12 & BS17 & 57 & $M$ & 0,02 & 29 & 0,15 & No \\
\hline 13 & BS18 & 54 & $M$ & 0,02 & 17 & 0,29 & No \\
\hline 14 & BS19 & 50 & $M$ & 0,02 & 13 & 0,35 & No \\
\hline 15 & BS22 & 30 & $M$ & 0 & 5 & 0,78 & No \\
\hline 16 & BS26 & 27 & W & 0,08 & 10 & 0,47 & No \\
\hline 17 & BS27 & 42 & W & 0 & 26 & 0,34 & No \\
\hline 18 & BS32 & 56 & $M$ & 0 & 30 & 0,26 & No \\
\hline 19 & PD-1 & 35 & $M$ & 0 & 15 & 0,31 & No \\
\hline 20 & PD-2 & 43 & $M$ & 0,02 & 8 & 0,45 & No \\
\hline 21 & PD-3 & 43 & $\mathrm{~W}$ & 0 & 10 & 0,32 & No \\
\hline 22 & PD-4 & 35 & $\mathrm{M}$ & 0 & 11 & 0,31 & No \\
\hline 23 & PD-5 & 54 & $W$ & 0 & 6 & 0,3 & No \\
\hline 24 & PD-6 & 34 & W & 0 & 13 & 0,33 & No \\
\hline 25 & PD-7 & 43 & W & 0 & 21 & 0,45 & No \\
\hline 26 & PD-8 & 37 & W & 0 & 13 & 0,33 & No \\
\hline 27 & PD-9 & 33 & W & 0 & 15 & 0,36 & No \\
\hline 28 & PD-10 & 33 & $W$ & 0,06 & 15 & 0,3 & No \\
\hline 29 & PD-11 & 32 & $W$ & 0,02 & 25 & 0,36 & No \\
\hline 30 & PD-12 & 44 & $W$ & 0 & 25 & 0,36 & No \\
\hline 31 & PD-13 & 51 & $M$ & 0 & 12 & 0,51 & No \\
\hline 32 & PD-14 & 38 & $M$ & 0 & 29 & 0,33 & No \\
\hline 33 & PD-15 & 44 & $M$ & 0 & 28 & 0,51 & No \\
\hline 34 & PD-16 & 27 & $M$ & 0,02 & 14 & 0,39 & No \\
\hline 35 & PD-17 & 55 & $M$ & 0 & 22 & 0,53 & No \\
\hline 36 & PD-18 & 49 & $\mathrm{M}$ & 0 & 18 & 0,41 & No \\
\hline 37 & PD-19 & 43 & W & 0 & 25 & 0,37 & No \\
\hline 38 & PD-20 & 49 & W & 0 & 20 & 0,44 & No \\
\hline 39 & PD-21 & 29 & $\mathrm{M}$ & 0,02 & 26 & 0,41 & No \\
\hline 40 & PD-22 & 56 & W & 0 & 27 & 0,38 & No \\
\hline 41 & BS11 & 58 & W & 0,08 & 24 & Control & No \\
\hline 42 & BS13 & 56 & $M$ & 0,02 & 25 & Control & No \\
\hline 44 & BS14 & 47 & $M$ & 0 & 25 & Control & No \\
\hline 45 & BS20 & 58 & W & 0,08 & 23 & Control & No \\
\hline 45 & BS21 & 56 & $M$ & 0 & 27 & Control & No \\
\hline 47 & BS24 & 41 & W & 0 & 29 & Control & No \\
\hline 48 & BS25 & 35 & W & 0 & 19 & Control & No \\
\hline 49 & BS28 & 40 & W & 0 & 18 & Control & No \\
\hline 50 & BS29 & 42 & W & 0 & 18 & Control & No \\
\hline 51 & BS30 & 41 & W & 0 & 14 & Control & No \\
\hline 52 & BS31 & 30 & W & 0,12 & 19 & Control & No \\
\hline 53 & PD-25 & 57 & W & 0,02 & 23 & Control & No \\
\hline 54 & PD-26 & 54 & W & 0 & 29 & Control & No \\
\hline 55 & PD-27 & 50 & W & 0 & 21 & Control & No \\
\hline 56 & PD-28 & 30 & $M$ & 0 & 9 & Control & No \\
\hline 57 & UL-1 & 28 & $\mathrm{M}$ & 0 & 12 & Control & No \\
\hline 58 & UL-2 & 27 & W & 0,02 & 16 & Control & No \\
\hline 59 & UL-4 & 42 & $M$ & 0 & 15 & Control & No \\
\hline 60 & UL-7 & 56 & $M$ & 0 & 15 & Control & No \\
\hline 61 & UL-9 & 53 & W & 0 & 14 & Control & No \\
\hline 62 & UL-11 & 26 & W & 0,02 & 16 & Control & No \\
\hline 63 & UL-12 & 25 & W & 0,02 & 20 & Control & No \\
\hline 64 & UL-20 & 28 & $M$ & 0 & 17 & Control & No \\
\hline 65 & UL-23 & 32 & $M$ & 0 & 25 & Control & No \\
\hline 66 & UL-24 & 35 & W & 0 & 14 & Control & No \\
\hline
\end{tabular}



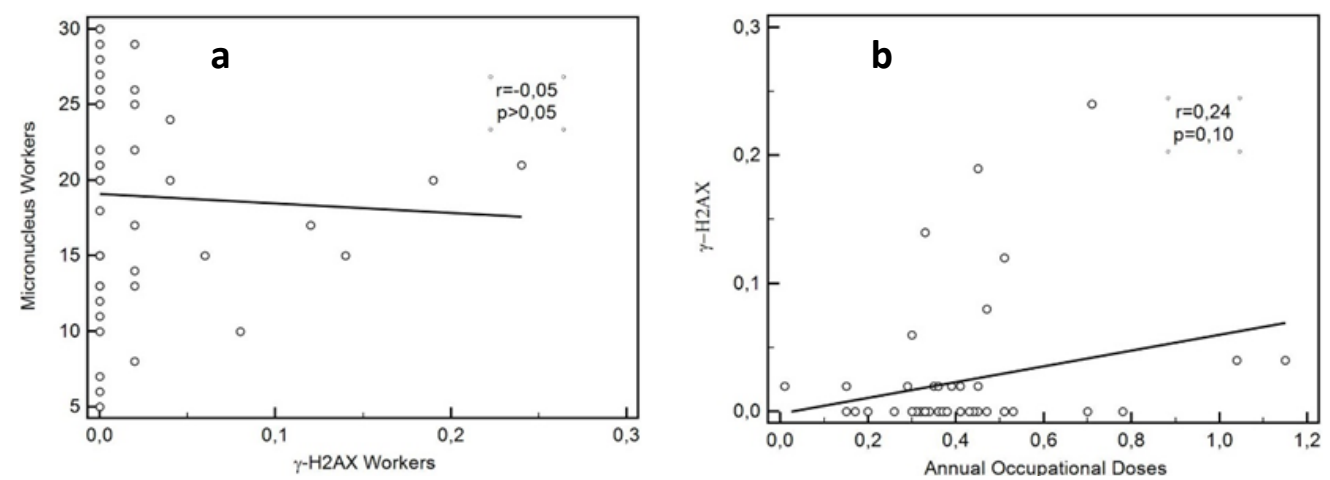

Figure 2. Correlation of $\mathrm{y}-\mathrm{H} 2 \mathrm{AX}$ index and micronuclei index (a) and $\mathrm{y}-\mathrm{H} 2 \mathrm{AX}$ index and annual occupational doses in workers (b).

\section{DISCUSSION}

Exposure of living organisms to genotoxic agents can induce several kinds of DNA damage, including DSBs. DSBs are considered to be lethal events as they result in the formation of exchange type chromosome aberrations and lead to clonogenic and mitotic cell death (30). However, in response to the formation of DSBs, some molecules of histone 2A (H2AX) occur in the chromatin part of the chromosome, flanking the break site, and they are rapidly phosphorylated. These in turn recruit several other molecules, facilitating DNA repair and chromatin remodeling. The site of DSB along with the protein molecules including the phosphorylated H2AX can be seen as foci which can be measured with flow cytometry and/or microscopy (18). The assay was adopted to quantify DNA DSBs in cells exposed in vitro and in vivo ${ }^{34,35)}$.

Micronuclei formation in cells cultured to division is another established biomarker of radiation exposure $(29,30,37,38,39)$, and the MultibioDose and RENEB networks have used this assay during triage simulation (40). The development of the cytokinesis-block technique has transformed the human-lymphocyte micronucleus assay into a reliable and precise method for assessing chromosome damage. Micronuclei are acentric chromosomal fragments, or whole chromosomes, lost during cell division because due to DNA damage. Formation is dependent on the capacity for DNA repair and the accumulation of DNA damage $(41,42)$.
The current observations suggest that occupational exposure to ionizing radiation does not cause significant DNA DSB damage, as observed by $\gamma$-H2AX and micronucleus induction in peripheral blood leukocytes of medical workers compared to controls. However, the range within the data suggests that the ranges of both $\gamma$-H2AX and micronuclei in workers are larger than the ranges in controls. Dobrzyńska et al. (41) reported that there were no statistical differences in DNA damage within females compared to males in both control and exposed persons. Pajic et al. (42) evaluated several cytogenetic parameters: chromosomal aberrations, premature centromere division, and micronuclei, and observed higher frequencies in the exposed (worker) group compared to controls. Moreover, it is not clear whether this could be related to cytogenetic damage observed by micronucleus appearance, as DNA DSB damage detected as $\gamma$-H2AX foci also were higher in workers when compared to controls. The lack of a significant difference between $\gamma$-H2AX foci and micronuclei frequency in workers and controls may be influenced by several confounding factors. Two published papers have reported that the expression of internal $\gamma$-H2AX foci is influenced by both the gender and age of volunteers, reported by Sharma et al. (44) and Siddiqui et al. (45). As with $\gamma$ -H2AX foci, micronuclei expression is also influenced by some confounding factors such as gender, age, and smoking habit. Gender, age, and smoking habit did not influence $\gamma$-H2AX frequencies in both control and exposed groups, except for parameters of micronucleus, where 
mean values were higher in females, smokers, and subjects older than 45 years of age $(41,42)$.

Interestingly, the current data suggest there was a tendency toward a negative correlation between expression of $\gamma-\mathrm{H} 2 \mathrm{AX}$ foci and micronuclei frequency. This may be associated with DNA DSB repair processes that prevent the formation of micronuclei related to any damage to cell division or chromosomal aberration(24-28). Expression of $\gamma$-H2AX foci showed a positive correlation to annual occupational dose estimates in workers, caused by the level of reactive oxygen species (ROS), including superoxide (02 •-), playing an important role in the biological effects of ionizing radiation(43). This could mean that a higher dose than expected was received by the workers, which could have the potential to affect the level of DNA DSB damage and may still be repaired, as shown in these results, the negative association between expression of $\gamma-\mathrm{H} 2 \mathrm{AX}$ foci and micronucleus frequency. No direct correlation between $\gamma$-H2AX foci and the occupational dose measured by an individual dosimeter was observed. The enrolled workers were only slightly exposed to IR. However, increased DNA repair activity was found in the IR-exposed group, and only subjects highly exposed to IR accumulated DNA damage in their circulating cells (figure 1). DNA damage has been considered as the most likely event to "kick-start" the multistep carcinogenic process (44). Therefore, an effective DNA repair system is essential to prevent mutations and, ultimately, cancer. Various DNA repair pathways are known to prevent the persistence of such DNA lesions. In particular, 8-oxoguanine glycosylase 1(OGG1) is one of the DNA repair enzymes associated with the susceptibility to tumor development (46). Gourabi and Mozdarani showed that radioresistance to higher doses of radiation in pre-exposed lymphocytes might bedue to initial DNA damage and an induced DNA repair mechanism (47). These findings support the "radiation hormesis model," which assumes that adaptive/protective mechanisms can be stimulated by low-dose radiation and that they can prevent both spontaneous and toxicant-related cancers, as well as other adverse health effects (48). Evidence of hormesis throughout defined low-dose ranges has been described (49). Although hormesis induced by chemical/physical exposure occurs in humans, such hormesis cannot be promoted to the public as a protective mechanism due to unresolved issues of safety, including the impossibility of controlling a "tolerable exposure" (48). Publications reporting a correlation between $\gamma$-H2AX foci annual occupational doses and micronuclei frequencies in the same subject are not common, and most of those published papers report only the relation of DNA DSB damage to radiation exposure $(15-20,30,31)$.

In conclusion, $\gamma$-H2AX foci have the potential to be used as an effective biomarker to detect DNA DSB damage in occupationally exposed IR workers. More intensive investigation is needed by reducing some of the confounding factors such as age and gender to fully appreciate the results of this study.

\section{ACKNOWLEDGMENT}

This paper was presented at the Association Radiation Research Congress in Manchester, England, in 2019. The first author's participation in the Congress was supported by the fund for fiscal year 2019 provided by the Directorate General of Strengthening Research and Development of the Indonesian Ministry of Research, Technology and Higher Education. This study was supported by the Research and Development budget of the Center for Technology of Radiation Safety and Metrology, National Nuclear Energy Agency, Indonesia. We would like to thank Mr. Abarrul Ikram, the head of the Center for Technology of Radiation Safety and Metrology, National Nuclear Energy Agency, for granting permission to conduct the study.

Conflicts of interest: Declared none. 


\section{REFERENCES}

1. UNSCEAR (1982) lonizing Radiation: Sources and Biological Effects, United Nations Scientific Committee on Effects of Atomic Radiation, New York.

2. Mettler FA, Huda W, Yoshizumi TT, Mahesh M. (2008) Effective doses in radiology and diagnostic nuclear medicine. A catalog, Radiology, 248: 254-263.

3. Delichas M, Psarrakos K, Molyvda AE, Gianoglou G, Sioundas A, Hatziioannou K, et al. (2000) Radiation exposure to cardiologists performing interventional cardiology procedures. Eur J Radiol, 48: 268-273.

4. Faulkner K and Werduch A (2008) An estimate of the collective dose to the European population from cardiac $X$ ray procedures. Br J Radiol, 81: 955-962.

5. Kim KP, Milder DS, Balter S, Ruth K, Martha SL, Kwon D, et al. (2008) Occupational radiation doses to operators performing cardiac catheterization procedures. Health Phys, 94: 211-227.

6. Brenner DJ, Doll R, Goodhead DT, Hall EJ, Land CE, Little JB, et al. (2003) Cancer risks attributable to low doses of ionizing radiation: assessing what we really know. U.S.A. Proc Natl Acad Sci, 100: 13761-13766.

7. Feinendegen LE, Brooks AL, Morgan WF (2011) Biological consequences and health risks of low-level exposure to ionizing radiation: commentary on the workshop. Health Phys, 100: 247-259.

8. Yoshinaga S, Mabuchi K, Sigurdson AG Doody MM, Ron E (2004) Cancer risks among radiologists and radiologic technologists: a review of epidemiologic studies. Radiology, 233(2): 313-321.

9. United Nations (2000) Scientific Committee on the Effects of Atomic Radiation. Sources and effects of ionizing radiation: Sources. United Nations Publications, Vol. 1.

10. Dobrzyńska MM, Pachocki KA, Gajowik A, Radzikowska J, Sackiewicz A. (2014) The effect occupational exposure to ionizing radiation on the DNA damage in peripheral blood leukocytes of nuclear medicine personnel. Journal of Occupational Health, 5: 5379-38.

11. Perumal V, Sekaran TSG, Raavi V, Basheerudeen SAS, Kanagaraj K, Chowdhury AR, et al. (2015) Radiation signature on exposed cells: relevance in dose estimation. World Journal of Radiology, 7(9): 266.

12. Coates PJ, Lorimore SA, Wright EG (2004) Damaging and protective cell signaling in the untargeted effects of ionizing radiation. Mutat Res, 568: 5-20.

13. Morgan WF and Sowa MB (2009) Non-targeted effects of ionizing radiation: implications for risk assessment and the radiation dose response profile. Health Phys, 97: 426-432.

14. Little MP (2010) Do non-targeted effects increase or decrease low dose risk in relation to the linear-non-threshold (LNT) model? Mutat Res, 17: 27687.

15. Wright EG (2010) Manifestations and mechanisms of nontargeted effects of ionizing radiation. Mutat Res, 687: 2833.

16. Costes SV, Chiolo I, Pluth JM, Hoff MHB, Jacob B. (2010) Spatio temporal characterization of ionizing radiation in- duced DNA damage foci and their relation to chromatin organization. Mutat Res, 704(1-3): 78-87.

17. Banáth JP, Klokov D, MacPhail SH, Banuelos CA, Olive PL. (2010) Residual gamma H2AX foci as an indication of lethal DNA lesions. BMC Cancer, 10: 4.

18. Rothkamm K and Horn S (2009) Gamma-H2AX as protein biomarker for radiation exposure. Ann Ist. Super Sanita, 45 (3): 265-71.

19. Salimi M and Mozdarani H (2014) [gamma]-H2AX as a protein biomarker for radiation exposure response in ductal carcinoma breast tumors: Experimental evidence and literature review. Int J Radiat Res, 12(1): 1-11.

20. Redon CE, Dickey JS, Bonner WM et al. (2009) Gamma$\mathrm{H} 2 \mathrm{AX}$ as a biomarker of DNA damage induced by ionizing radiation in human peripheral blood lymphocytes and artificial skin. Adv Space Res, 43(8): 1171-8.

21. Mendelsohn ML (1991) An introduction to biological dosimetry. In: Gledhill BL, Mauro F, eds. New Horizons in Biological Dosimetry. New York: Wiley-Liss Inc 1-10 (1991).

22. Wong KF, Siu LL, Ainsbury E, et al. (2013) Cytogenetic biodosimetry: what it is and how we do it. Hong Kong Med J, 19(2): 168-173.

23. Rogakou EP, Boon C, Redon C, Bonner WM. (1999) Megabase chromatin domains involved in DNA doublestrand breaks in-vivo. J Cell Biol. 146(5)905-16.

24. IAEA (2001) Cytogenetic Analysis for Radiation Dose Assessment (2001) A Manual technical reports series no. 405, International Atomic Energy Agency Vienna.

25. Thierens H (1999) Inter-laboratory comparison of cytogenetic endpoints for the biomonitoring of radiological workers. Int J Radiat Biol, 75: 23-34.

26. Thierens $\mathrm{H}$ and Vral A (2009) The micronucleus assay in radiation accidents. Ann Ist Super Sanita, 45: 260-264.

27. Touil N, Aka PV, Buchet JP, Thierens H, Volders MK. (2002) Assessment of genotoxic effects related to chronic low level exposure to ionizing radiation using biomarkers for DNA damage and repair. Mutagenesis, 17: 223-232.

28. Song EY, Rizvi SM, Qu CF, Raja C, Yuen J, Li Y, et al. (2008) The cytokinesis-block micronucleus assay as a biological dosimeter for targeted alpha therapy. Phys Med Biol 53: 319-328.

29. Fenech M (2010) The lymphocyte cytokinesis-block micronucleus cytome assay and its application in radiation biodosimetry. Health Phys, 98: 234-243.

30. Fenech M (2007) Cytokinesis-block micronucleus cytome assay. Nat Protoc, 2: 1084-1104.

31. Basri IKH, Yusuf $D$, Rahardjo $T$, Nurhayati $S$, Tetriana $D$, Ramadhani D, et al. (2017) Study of $\gamma-\mathrm{H} 2 \mathrm{AX}$ as DNA double strand break biomarker in residents living in high natural radiation area of Mamuju, West Sulawesi. Journal of Environmental Radioactivity, 171: 212-216.

32. Kurnia I, Lusiyanti Y, Rahejeng N (2018) Expression of $Y$ $\mathrm{H} 2 \mathrm{AX}$ in nuclear medicine and cath lab as medical radiation workers. The Proceedings Book of the 8th Annual Basic Science International Conference, 357-362.

33. German U, Ben-Shachar B, Weinstein M (2000) Twentyfive years of TL-dose measurements at the NRC-NEGEV. In:

Int. J. Radiat. Res., Vol. 19 No. 4, October 2021 
Proceedings of IRPA-10; Hiroshima, Japan: International Radiation Protection Assocation: CD ROM paper $\mathrm{p} 3 \mathrm{~b}-168$.

34. Ismail IH, Wadhra TI, Hammarsten OI (2007An optimized method for detecting gamma-H2AX in blood cells reveals a significant interindividual variation in the gamma- $\mathrm{H} 2 \mathrm{AX}$ response among humans. Nucleic Acids Res, 35(5): e36.

35. Roch-LS, Mandina T, Voisin P, Gaetan G, Gonzallez MJE, Valente $M$ et al. (2010) Quantification of gamma-H2AX foci in human lymphocytes: a method for biological dosimetry after ionizing radiation exposure. Radiat Res, 174(2): 185-194.

36. Sak A, Grehl S, Erichsen P, Engelhard M, Granna A, Levegrun S. et al. (2007) Gamma-H2AX foci formation in peripheral blood lymphocytes of tumor patients after local radiotherapy to different sites of the body: dependence on the dose-distribution, irradiated site and time from the start of treatment. Int J Radiat Biol, 83(10): 639-652.

37. Fenech M and Morley AA (1985) Measurement of micronuclei in lymphocytes. Mutat Res, (147): 29-36.

38. Vral A, Fenech M, Thierens $H$ (2011) The micronucleus assay as a biological dosimeter of in-vivo ionising radiation exposure. Mutagenesis, 26: 11-7.

39. Soren DC, Toprani SM, Jain V, Saini B, Das B (2019) Quantitation of genome damage and transcriptional profile of DNA damage response genes in human peripheral blood mononuclear cells exposed in vitro to low doses of neutron radiation. Int J Radiat Res, 17(1): 1-14.

40. Depuydt J, Baeyens A, Barnard S, et al. (2017) RENEB intercomparison exercises analyzing micronuclei (Cytokinesisblock Micronucleus Assay). Int J Radiat Biolo, 93(1): 36-47.

41. Dobrzyńska M M, Pachocki K A, Gajowik A, Radzikowska J, Sackiewicz A (2014) The effect of occupational exposure to ionizing radiation on the DNA damage in peripheral blood leukocytes of nuclear medicine personnel. Journal of Occupational Health, 56(5): 379-386.
42. Pajic J, Rakic B, Jovicic D, et al. (2016) A cytogenetic study of hospital workers occupationally exposed to radionuclides in Serbia: premature centromere division as novel biomarker of exposure? International Archives of Occupational and Environmental Health, 89(3): 477-484.

43. Sharma PM, Ponnaiya B, Taveras M, et al. (2015) High throughput measurement of $\mathrm{YH} 2 \mathrm{AX}$ DSB repair kinetics in a healthy human population. PloS One, 10(3): e0121083.

44. Siddiqui MS, François M, Fenech MF, Leifert WR (2015) Persistent $\mathrm{\gamma H} 2 \mathrm{AX}$ : A promising molecular marker of DNA damage and aging. Mutation Research/Reviews in Mutation Research, 766: 1-9.

45. Langie S A, Koppen G, Desaulniers D, Al-Mulla F, AlTemaimi R, Amedei A. et al. (2015) Causes of genome instability: the effect of low dose chemical exposures in modern society. Carcinogenesis, 36: S61-S88.

46. Gaetani S, Monaco F, Bracci M, et al. (2018) DNA damage response in workers exposed to low-dose ionising radiation. Occupational and Environmental Medicine, 75(10): 724-729.

47. Gourabi H and Mozdarani H (1998) A cytokinesis-blocked micronucleus study of the radioadaptive response of lymphocytes of individuals occupationally exposed to chronic doses of radiation. Mutagenesis, 13(5): 475-480.

48. Vaiserman AM (2010) Radiation hormesis: historical perspective and implications for low dose cancer risk assessment. Dose Response, 8: 172-191.

49. Crump KS, Duport P, Jiang H, Shilnikova NS, Krewski D, Zielinski JM (2012) A meta-analysis of evidence for hormesis in animal radiation carcinogenesis, including a discussion of potential pitfalls in statistical analyses to detect hormesis. J Toxicol. Environ. Health B Crit Rev, 15: 210-31. 
